\title{
The Concept of Being Scandinavian-American
}

\section{Jørn Brøndal and Dag Blanck}

University of Southern Denmark and Uppsala University

In 1878 O.L. Kirkeberg, a Norwegian-born pastor working primarily among Danish-American congregations, stopped over in Salina, Kansas, on his way to the settlement of Denmark further out west. Asking a local hotelkeeper whether he knew of any Scandinavians in town, the latter answered in the affirmative. Kirkeberg then wanted to know whether there were any Danes among them, or Norwegians, or Swedes? "No," answered the hotelkeeper, "There don't seem to be representatives of those nationalities, most are Scandinavians."'

The episode is interesting because it highlights the terms on which Scandinavian Americans met native-born white Americans in the United States in the late nineteenth century. To the presumably Yankee hotelkeeper, people of Danish, Norwegian and Swedish origin were at most Scandinavians - that term represented his high point of ethnic sophistication - he could not go beyond that level and talk meaningfully about Danes, Norwegians and Swedes. To Kirkeberg, on the other hand, the Scandinavian label represented the lowest common ethnic denominator. To him undoubtedly it made even more sense to speak about Danes, Norwegians and Swedes.

Indeed, by the second half of the nineteenth century, to many Scandinavian immigrants, even their nationality was only just beginning to take on meaning. Many of them remained steeped in cultural traditions that were rooted in landscapes and even parishes rather than nation states. ${ }^{2}$

1. Højskolebladet, Kolding, Denmark, June 14, 1878, 371.

2. Jon Gjerde, "The effect of community on migration: three Minnesota townships 1885-1905," Journal of Historical Geography, 5: 4 (1979), 406. 
The depth of regional loyalties is conveyed, for instance, by a secondgeneration Norwegian American declaring his attachment to Sogn, even though he had never visited Norway, or by the Swedish-American journalist Johan Person claiming that the loyalties of Swedish immigrants rested within provinces rather than in the Swedish nation, and that it was the identifications of the surrounding American society that made it important to address the question of what it meant to be Swedish-American. ${ }^{3}$

The episode in Salina demonstrates that there was both a "Scandinavian" and an "American" side to being labeled a Scandinavian, or a Scandinavian American. Those labels, incidentally, were used interchangeably, along with the parallel pairs, Norwegian and Norwegian-American, Swedish and Swedish-American and Danish and Danish-American. Over time, however, the "American" appendage became increasingly popular, seemingly expressing loyalty to the new nation and reflecting the decline in the number of Scandinavian Americans actually born in the Old World. In this article we will explore the ways in which the ethnic label Scandinavian-American has been used and what it has meant during the nineteenth and twentieth centuries. The discussion will focus on its relationship to the national Scandinavian ethnic identities and on how the term can be seen in the larger context of how ethnic identities have evolved and functioned in the U.S.

The construction and use of ethnic identities remains a salient feature in American social life. The "ideological quality" of American nationalism has often been commented upon, suggesting that becoming American did not require a particular national, linguistic, religious or ethnic background. It was, according to Philip Gleason, a matter of committing to the abstract political ideals of liberty, equality and republicanism, as the framers of the constitution, in the words of Nathan Glazer, "did not define their Americanness as an ethnic characteristic," but rather emphasized its universality. ${ }^{4}$

A pluralistic society thus developed in the United States, which

3. J.O. Taylor to Skandinaven, Chicago, February 17, 1897; Johan Person, Svenskamerikanska studier (Rock Island, Ill., 1912), 114-117.

4. Philip Gleason, "American Identity and Americanization," in Stephan Thernstrom (ed.), Harvard Encyclopedia of American Ethnic Groups (Cambridge, Mass., 1980), 32; Nathan Glazer, We Are All Multiculturalists Now (Cambridge, Mass., 1997), 99. 
allowed for the development and maintenance of specific ethnic traditions and cultures. It is, however, important to note that pluralism was only extended to certain parts of American society. Lawrence Fuchs has made an important distinction between "voluntary" and "coercive" pluralism, in which voluntary pluralism included those groups who had migrated to the U.S. voluntarily, and thus encompassed, for example, immigrants from Europe. These migrants were able to both maintain and promote their own cultures and religion, or in Fuchs' words, were "free...to choose to be ethnic," a choice which was "sanctioned and protected" by American civic culture. ${ }^{5}$

The involuntary migrants, on the other hand, such as the slaves from Africa and their descendants, were not given the choice of belonging to the new American nation. They were instead subjected to "coercive pluralism," a policy which kept them outside the American polity, and made it impossible to develop their own cultural and ethnic patterns in the same way as the voluntary migrants. ${ }^{6}$ In this way, the internal logic of American nationalism accepted and even approved of what we could call "ethnic and cultural rights" for Scandinavian Americans, while at the same time denying these rights to groups such as African Americans, Chinese immigrants and Native Americans.

Within this larger framework of American nationality, immigrant groups created and maintained ethnic identities - a process which has sometimes been called ethnicization. ${ }^{7}$ There are several important dimensions behind this process. One such is the subjective-objective dichotomy. Ethnic identity can either be defined by the group members themselves - which can be called a subjective or descriptive identity - or by the surrounding society, in which case it is known as an objective or ascriptive identity. Moreover, it is important to distinguish between the view of ethnicity and ethnic identities as primeval and enduring, so deeply rooted in human nature that they remain unchangeable and almost constant, and the view which underscores the changing and malleable

5. Lawrence Fuchs, The American Kaleidoscope: Race, Ethmicity, and the Civic Culture (Hanover, N.H., 1990), 5 .

6. Fuchs $1990,77-79$.

7. Kathleen Nails Conzen et al., "The Invention of Ethnicity: A Perspective from the U.S.A.," Journal of American Ethnic History, 12 (Fall 1992); Jonathan Sarna, "From Immigrants to Ethnics: Toward a New Theory of 'Ethnicization'," Ethnicity, 5 (December 1978). 
nature of ethnicity, emphasizing how it can be used in different ways and describing ethnic groups as interest groups, mobilizing to achieve certain goals. ${ }^{8}$

The ethnic consciousness among those Scandinavian immigrants who arrived in America during the nineteenth century was, as already noted, fairly weak. The process through which national identities developed in the Scandinavian countries in the nineteenth century was uneven, but even so it is also clear that local and regional patterns of identification were important, at least during much of the nineteenth century. In many cases it was not until the immigrants came to the United States that they became Danes, Norwegians or Swedes - or more accurately Danish Americans, Norwegian Americans or Swedish Americans.

This process of ethnicization was both descriptive and ascriptive. It took place from within as the groups themselves mobilized and actively provided answers to the question of what it meant to be Danish, Norwegian and Swedish in the United States. It was also located outside the ethnic groups, as the Scandinavian immigrants were establishing themselves in the American social fabric, interacting and competing with other immigrant and ethnic groups. Their ethnicities thus became a vehicle in their integration into American society, emanating from both the need for ethnic self-assertion and as a reaction to circumstances created by the surrounding American society - Yankee and ethnic alike. ${ }^{9}$

The fact that Danish, Norwegian and Swedish immigrants were often grouped together as "Scandinavians" or "Scandinavian Americans" adds a further layer of complexity to the process. The term Scandinavian American is vaguer and obviously much more inclusive than the nationally based terms Danish, Norwegian and Swedish American, and has been used in different ways. One usage has been to describe a process through which Scandinavian immigrants in the U.S. rather unsuccessfully sought to establish pan-Scandinavian patterns of cooperation. Another relates to how American society, unwilling or uninterested in distinguishing between the three groups, has adopted the collective term

8. Cf. Milton Yinger, Ethnicity: Source of Strength? Source of Conflict? (Albany, N.Y., 1994); Conzen et al. 1992; Nathan Glazer and Daniel Patrick Moynihan (eds.), Ethnicity: Theory and Experience (Cambridge, Mass., 1975).

9. For a sensitive and nuanced discussion of this process, see Jon Gjerde, The Minds of the West: Ethnocultural Evolution in the Rural Middle West, 1830-1917 (Chapel Hill, N.C., 1997). 
to describe them as one. Yet another way has been to utilize it instead of one of the three national labels, as has been common, for example, in the names of many organizations. Let us now in some greater detail examine the ways in which the term has been used over a period of more than 150 years of Scandinavian presence in the United States.

\section{The era c. $1840-1890$}

Arguably, the American conditions for nurturing a sense of Scandinavianhood were never as favorable as during the early years of Scandinavian mass migration to America. First, due to the relatively small numbers of Scandinavian immigrants, especially prior to the Civil War, being too picky about the choice of Scandinavian acquaintances in daily life seemed ill-advised, for there was a risk, simply, of being swallowed heart and soul by the American environment. As one 1892 commentator, looking back on the pioneer days, noted, "it must be remembered that, fifty or sixty years ago, the Scandinavian nationalities were completely lost in the ocean of American life ... and they had no choice but to drift with the current." 10 Ideally, at least, small numbers should inspire panScandinavian cooperation among immigrants in a strange environment. Second, especially during the 1840 s and early 1850 s, coinciding with the arrival of many Irish and German immigrants, the United States experienced a wave of nativism. Even though it was aimed primarily at Catholics, Yankee bigotry might also hurt Scandinavian immigrants, as when some were either labeled "Norwegian Indians" due to their supposed political ignorance, or compared unfavorably with African Americans. ${ }^{11}$ If Scandinavian greenhorns might thus sometimes be inspired to group together in the face of adversity, their foreign surroundings also ascribed to them common traits. In Minneapolis of the $1850 \mathrm{~s}$ and $1860 \mathrm{~s}$,

10. H.H. Boyesen, "The Scandinavian in the United States," North American Review, 155 (November 1892), 533.

11. Bayrd Still, "Norwegian-Americans and Wisconsin Politics in the Forties," Norwegian-American Studies and Records, 8 (1934), 58-59; Theodore C. Blegen, Norwegian Migration to America, 1825-1860 (Northfield, Minn., 1931), 259. 
Norwegians were sometimes dubbed "Swedes" by their Yankee surroundings for whom the two nationalities obviously represented just one group. ${ }^{12}$

Superficially, the Scandinavian conditions for cultivating Scandinavianism were also good in the early years, for within the Scandinavian region a political Scandinavianism budded during the 1840 s, reaching from the student level up to the royal, but suffering a severe setback in 1864 when Sweden declined to offer Denmark assistance in her losing war against Prussia. ${ }^{13}$ This elite movement, however, had little impact on ordinary Scandinavians.

A brief overview of a number of important spheres of public and private activity for Scandinavian immigrants suggests that some sort of panScandinavian cooperation was in fact realized in the years between 1840 and 1890 , but that it varied from sphere to sphere.

The central ethnic institution built in the American Middle West during the formative years of Scandinavian immigration was the church. ${ }^{14}$ In the early years, pan-Scandinavian religious cooperation sometimes became important. Thus, the Swedish-American Augustana Synod, by the end of the nineteenth century clearly the largest "national" Swedish-American denomination, had part pan-Scandinavian roots dating back to 1851 when the Evangelical Lutheran Synod of Northern Illinois was founded out of English, German, Norwegian and Swedish elements. ${ }^{15}$ In 1860 , however, most Scandinavian Americans seceded and formed the Scandinavian Evangelical Lutheran Augustana Synod. The Scandinavian formula was employed only with modesty, however, for it was feared that the Synod might be suspected of wanting to retard Americanization. At this early point in time, Swedish-American leaders simply did not envision the creation of a distinctly national church in America. Indeed, orig-

12. John R. Jenswold, "The Rise and Fall of Pan-Scandinavianism in Urban America," in Odd S. Lovoll (ed.), Scandinavians and Other Immigrants in Urban America: The Proceedings of a Research Conference, October 26-27, 1984 (Northfield, Minn., 1985), 160.

13. Kristian Hvidt, Det folkelige gennembrud og dets mand, 1850-1900, vol. 11 of Olaf Olsen (ed.), Gyldendal og Politikens Danmarkshistorie (Copenhagen 1990), 119-120.

14. Robert C. Ostergren, "The Immigrant Church as a Symbol of Community and Place in the Upper Midwest," Great Plains Quarterly, 1 (Fall, 1981), 225.

15. George M. Stephenson, The Religious Aspects of Swedish Immigration: A Study of Immigrant Churches (Minneapolis 1932), 165-166. 
inally, Lutheran pioneer Tufve Nilsson Hasselquist expected that the language of the new ecclesiastical body would be English. ${ }^{16}$ In 1870, the "Scandinavian" title became obsolete when Norwegian Americans with a smattering of Danish Americans left the Augustana Synod (which thus emerged as purely Swedish-American), soon to form the NorwegianDanish Lutheran Conference from which the Danes, in turn, withdrew in $1884 . .^{17}$

A similar "national" differentiation from pan-Scandinavian beginnings characterized the growth of the Scandinavian-language press. Thus, Skandinavia, the very first Scandinavian-language paper in America, coming out briefly in New York City in 1847, carried columns in both Norwegian-Danish and Swedish; the New York Skandinaven, lasting from 1851 to 1853 , was a rather similar venture. ${ }^{18}$ In the case of the press, the crystallization along nationality lines proceeded especially rapidly, the Norwegian-American Nordlyset appearing in 1847, the SwedishAmerican Hemlandet in 1855 and the Danish-American Fremad in $1868 .{ }^{19}$ By 1894 , noted one observer, Swedish Americans and Norwegian Americans did not read the same newspapers. ${ }^{20}$ Danish and Norwegian immigrants, on the other hand, had no difficulty reading each other's papers. Characteristically, the Scandinavian Press Association, established in 1883, soon gave way to a Norwegian-Danish Press Association, founded in 1895 and still in existence by the outbreak of World War One. ${ }^{21}$

Due to the widespread phenomenon of chain migration from one location in the Old World to one or a couple in the Middle West, in their rural

16. Stephenson 1932, 311.

17. Henrik Bredmose Simonsen, Kampen om Danskheden: Tro og nationalitet $i$ de danske kirkesamfund $i$ Amerika (Århus 1990), 23 and 46-47; Stephenson 1932, 195.

18. Blegen 1931, 132; Marion Tuttle Marzolf, The Danish-Language Press in America (N.Y. 1979), 29 30; H. Arnold Barton, A Folk Divided: Homeland Swedes and Swedish Americans, 1840-1940 (Carbondale, Ill., 1994), 34 .

19. Odd Lovoll, The Promise of America: A History of the Norwegian-American People (Minneapolis 1984), 41; Stephenson 1932, 180; Marzolf 1979, 31.

20. Nils P. Haugen to J.J. Jenkins, September 7, 1894, the Papers of Nils P. Haugen, State Historical Society of Wisconsin.

21. Johs. B. Wist, "Pressen efter Borgerkrigen," in Wist (ed.), Norsk-Amerikanernes Festskrift 1914 (Decorah, Iowa, 1914), 188-191. 
settlement patterns Scandinavian immigrants tended to remain nationally exclusive, whenever their numbers permitted it. Indeed, in some Midwestern counties, with immigration mounting, some settlers of Norwegian and Swedish background could actually afford the luxury of socializing mostly with people of their own regional background. In Goodhue County, Minnesota, reported one observer in 1898, many Norwegian immigrants had "settled down, so to speak, in small Bygdelag."22

Nevertheless, some of the earliest settlements were pan-Scandinavian in character, among them the Pine Lake colony that was established by Swedish-American Gustaf Unonius in Waukesha County, Wisconsin, in 1841 and also attracted a Swedish baron and a former member of the Norwegian Parliament, as well as a Danish-educated attorney and newspaper editor. ${ }^{23}$ By the early 1850 s, however, the settlement had been vacated by most of its original settlers; quite symptomatically, a DanishAmerican colony (the earliest such in America) soon emerged from these pan-Scandinavian beginnings. ${ }^{24}$ Judging by name patterns, other settlements also had Scandinavian roots. One Minnesota settlement was thus named Swenoda as an abbreviated compound of "Swedish," "Norwegian" and "Danish," and yet others "Scandinavia."25

In cases where Scandinavian immigrants of different national backgrounds dwelled together, ethnic tensions could surface. Indeed, one student of Scandinavian America suggested that in the early settlements, the "Scandinavian" label was sometimes adopted as a compromise term where "the members of one [nationality group] were inclined, in an outburst of latent pride of nationality ... to resent being called by one of the other names; for example, when a Norwegian objected to being taken for a Swede."26

As several observers have noted, prior to 1890 genuinely pan-Scandinavian enclaves emerged quite commonly in cities such as Minneapolis,

22. Knut Takla to Skandinaven, July 8, 1896 (transtated from the Norwegian).

23. Albert O. Barton, "The Scandinavian Element in Wisconsin," in Milo M. Quaife (ed.), Wisconsin: Its History and Its People, 1634-1924, II (Chicago 1924), 118-119; Torben Grøngaard Jeppesen, Damnebrog på den amerikanske prarie: Et dansk koloniprojekt i 1870'erne - landkøb, bygrundlaggelse og integration (Odense 2000), 44.

24. Grøngaard Jeppesen 2000, 47-48.

25. Blegen 1940, 97.

26. Kendrick C. Babcock, The Scandinavian Element in the United States (Urbana, Ill., 1914), 15. 
Chicago and New York. ${ }^{27}$ In these metropolitan areas, pan-Scandinavian ventures of various sorts also soon budded. Thus, as early as 1844 a Scandinavian fraternal society was established in New York with the idea, among other things, of bringing Norwegian, Swedish and Danish immigrants together to enable them to read newspapers and books from the mother countries. As the Norwegian-educated Pastor J.W.C. Dietrichson noted with measured enthusiasm, "The idea is very good and will be a means of uniting the Scandinavian brethren in New York if it does not, as with so many other things, go up in smoke." ${ }^{28}$ In 1854 a Scandinavian Union was likewise founded in Chicago. ${ }^{29}$ In the wake of these early organizational beginnings followed a welter of other "Scandinavian" groups, stretching from literary societies over singing associations, brass bands, temperance lodges, athletic clubs and rifle associations to banks, mutual-aid fraternities and trade-union locals. ${ }^{30}$

True pan-Scandinavianism at the level of everyday life was expressed in marriage, a strong indicator of interaction and acceptance between different social groups. ${ }^{31}$ As Jon Gjerde and Robert C. Ostergren have demonstrated, many of the Scandinavian immigrants settling in the rural Midwest took with them Old-World patriarchal traditions in which marriage alliances were based on the attachment to the scarce soil. To the degree that these immigrants participated in patterns of successful chain

27. Jenswold 1985, 159; Odd S. Lovoll, "A Scandinavian Melting Pot in Chicago," in Philip J. Anderson and Dag Blanck (eds.), Swedish-American life in Chicago: Cultural and urban aspects of an immigrant people, 1850-1930 (Uppsala 1991); John Robert Christianson, "Scandinavian-Americans," in John D. Buenker og Lorman A. Ratner (ed.), Multiculturalism in the United States: A Comparative Guide to Acculturation and Ethnicity (Westport, Conn., 1992), 112; Harald Runblom, "A Nordic Melting Pot or "Unmelting Pot" in North America," in Birgit Flemming Larsen et al. (eds.), On Distant Shores: Proceedings of the Marcus Lee Hansen Immigration Conference Aalborg, Denmark June 29-July 1, 1992 (Aalborg 1993), 233; B. Lindsay Lowell, "The Scandinavians," in Mary Kupiec Cayton et al. (eds.), Encyclopedia of American Social History, vol. 2 (N.Y. 1993), 707; Lovoll 1991, 63.

28. E. Clifford Nelson (ed.), A Pioneer Churchman: J.W.C. Dietrichson in Wisconsin, 1844-1850 (N.Y. 1973), 55. In Philadelphia a Scandinavian society claimed to reach back to 1768, cf. Carl Hansen, "Det norske foreningsliv i Amerika," in Wist 1914, 268.

29. Jenswold 1985, 159-160; Ulf Beijbom, Swedes in Chicago: A Demographic and Social Study of the 1846-1880 Immigration (Uppsala 1971), 285.

30. Hansen 1914, 266-268; Beijbom 1971, 275-279; Jenswold 1985, 160-161; Lovoll 1991, 65; David Mauk, The Colony That Rose From the Sea: Norwegian maritime migration and community in Brooklyn, 1850-1910, 88-89 and 172 .

31. Paul Spickard, Mixed Blood: Intermarriage and Ethmic Identity in Twentieth-Century America (Madison, Wis., 1989). 
migration, they tended to look for spouses among people of similar local origins. ${ }^{32}$ Even so, in ethnically more heterogeneous areas, instances of Scandinavian-American intermarriage were reported. In Marinette county, Wisconsin, noted one observer, the phenomenon of SwedishAmerican men marrying Norwegian-American women had by 1892 led to a situation where the men spoke their language with a Norwegian intonation; "indeed, in the Scandinavian settlements in the inner part of the state, it is meaningful to speak of a "Scandinavian language." 33 That Scandinavian partners were generally preferred over spouses from other ethnic groups during the latter half of the nineteenth century may be deduced from the circumstance that in Wisconsin by 1900 people of mixed Scandinavian parentage slightly outnumbered those of mixed Scandinavian and other foreign parentage. ${ }^{34}$

In the cities rather similar circumstances prevailed. In Chicago, where at least the Swedish-American gender balance was strikingly equal even in the 1860 s and 1870 s, rates of Swedish-American endogamy were high; judging by the 1880 census, Norwegian-American rates were even higher, whereas Danish-American were lower, reflecting their greater geographical dispersal. ${ }^{35}$ On the American west coast, the large surplus of single Scandinavian-American males led to especially high rates of exogamy. ${ }^{36}$ Again, to the extent that intermarriage took place in the cities, Scandinavian Americans tended to find their spouses among fellow Scandinavian Americans and, to some extent, among German Americans. $^{37}$

Thus far, we have been dealing with patterns of life and types of institutions in which the Scandinavian Americans were free, more or less, to

32. Jon Gjerde, "Conflict and Community: A Case Study of the Immigrant Church in the United States," in Journal of Social History, 19 (1986), 683-684; Robert C. Ostergren, A Community Transplanted: The Trans-Atlantic Experience of a Swedish Immigrant Settlement in the Upper Middle West, 1835-1915 (Madison, 1988), 318; see also John G. Rice, "Marriage Behavior and the Persistence of Swedish Communities in Rural Minnesota," in Nils Hasselmo (ed.), Perspectives on Swedish Immigration: Proceedings of the International Conference on the Swedish Heritage in the Upper Midwest, April 1-3, 1976 (Duluth, 1976), 146.

33. Gamla och nya hemlandet, Rock Island, Ill., October 20, 1892 (translated from the Sweedish).

34. Calculated from data in the U.S. Census, 1900, vol. 1, 850-865. Non-Scandinavian immigrants far outnumbered Scandinavian in Wisconsin in 1900.

35. Beijbom 1971, 125 and 136-137; Lovoll 1991, 64-65.

36. Christianson 1992, 113.

37. Cf. Runblom 1993, 235; Beijbom 1971, 136-137. 
define Scandinavian-American identities subjectively, on their own terms. In one other sphere, however, that of politics, circumstances were different. Here, much more so than in the private or the religious spheres, Scandinavian Americans had to come to terms with rules defined strictly by the American environment. Characteristically, on this stage the Scandinavian label was employed quite commonly.

The growing political strength of the Scandinavian Americans was recognized in 1859 when the first Scandinavian Americans appeared on Midwestern state tickets, those of the Democratic and Republican parties of Wisconsin. ${ }^{38}$ With the coming of the Civil War and with ScandinavianAmerican soldiers thus dying on the battlefield, the Scandinavian Americans further strengthened particularly their Republican credentials. Indeed, in the second half of the nineteenth century the Republican party in some Midwestern states routinely nominated a "Scandinavian," as well as a "German" for state office in a general effort to create an ethnically and regionally "balanced" state ticket. ${ }^{39}$

Even though this type of politics was ethnically oppressive in that some politicians were meted out positions symbolically on the basis of ethnicity rather than individual merit, many Scandinavian-American politicians and newspaper editors accepted the rules of the game. Indeed, from several Midwestern Republican state conventions came reports of Scandinavian-American politicians holding their own caucuses, and the Scandinavian-language press also kept up a steady stream of demands for political representation, quite frequently employing the Scandinavian label: in politics, after all, the more votes, the better. ${ }^{40}$ When the Norwegian-born Republican Knute Nelson won the governorship of Minnesota in 1892, the Norwegian-language Skandinaven of Chicago thus declared, "We have now reached a turning point in the history of the Scandinavians in this country.... Our brothers the Swedes have shown that they under-

39. Jørn Brøndal, "National Identity and Midwestern Politics: Scandinavian-American Involvement in the Progressive Movement of Wisconsin, c. 1890-1914," Ph.D. dissertation (Copenhagen 1998), 283-284; Skandinaven, June 1, 1892.

40. Nils P. Haugen to K. Knudson, June 15, 1894, the Papers of Nils P. Haugen; Millard L. Gieske and Steven J. Keillor, Norwegian Yankee: Knute Nelson and the Failure of American Politics, 1860-1923 (Northfield, Minn., 1995), 150. 
stand how to appreciate the meaning of this political victory." 41 When Nelson was inaugurated as governor, the paper further exulted, "A greater day of honor the Scandinavians in America have not experienced since Leif Ericson discovered this continent." 42 Thus, even though in this case the Norwegian-American press might easily come under suspicion for using the Scandinavian label for national ends, it was nevertheless employed actively in political rhetoric.

With pan-Scandinavianism playing a role in the daily life of many Norwegian, Swedish and Danish Americans, and with the Scandinavian label being accepted in post-Civil War political rhetoric by Yankees and Scandinavian Americans alike, one might have expected that attempts would have been made to build a specific Scandinavian-American identity in the years 1840 to 1890 . That only happened to a limited extent, however. Celebrating the Norwegian syttende mai as a Scandinavian affair in some metropolitan areas in the 1870s and 1880s hardly seemed altogether convincing, and an 1876 "Scandinavian" July Fourth float in Worcester, Massachusetts, with representatives from all three nationalities yet crowned by a girl symbolizing Svea alone was not much more persuasive. ${ }^{43}$ Again, the Manhattan Norwegian Americans may have been generous in inviting Swedish Americans to participate in a festival commemorating Leif Ericson, the discoverer of Vinland, yet generally the Norwegian Americans soon faced accusations of arrogating the whole viking legacy, and when in 1879 the Norwegian-born principal O.L. Kirkeberg named the essentially Danish-American folk highschool at Elkhorn, Iowa, "Leif Ericsøns Minde," some Danish Americans were dismayed. ${ }^{44}$ Leif Ericson, quipped a Swedish-American newspaper years later, was Icelandic rather than Norwegian. ${ }^{45}$

The ambiguous nature of these celebrations notwithstanding, some early commentators definitely did express their enthusiasm for a panScandinavian-American identity. Thus, in an 1847 emigrant guide, the

41. Skandinaven, November 2, 1892 (translated from the Norwegian).

42. Skandinaven, January 4, 1893 (translated from the Norwegian).

43. Lovoll 1991, 62; Jenswold 1985, 161-162; Runblom 1993, 231. The summer Skandinavisk Fest in Minneapolis of the 1880 s mentioned by Jenswold may have been more pan-Scandinavian-American. See also David Mauk's article in the present issue.

44. Højskolebladet, August 8, 1879; Jenswold 1985, 161-162.

45. Svenska Amerikanska Tribunen, Superior, Wis., August 24, 1906. 
Danish-born L.J. Fribert noted idealistically of the Pine Lake colony: "Where men from the three Scandinavian nations come together, they view each other as fellow nationals and help each other as brothers, and the endeavors to create harmony and good mutual understanding between the three kingdoms that are presently under way have already been realized long ago in America which thus also in this respect rushes ahead of Europe."46 Likewise commenting on the Pine Lake settlement, Fredrika Bremer, the Swedish author, exclaimed, "A new Scandinavia shall one day bloom in the valley of the Mississippi in the great assembly of peoples there...." In terms equally glowing she exulted, "What a glorious new Scandinavia might not Minnesota become!"47

Neither Fribert nor Bremer was in a position, however, to make truly programmatic statements on behalf of the Scandinavian Americans, for the former was addressing would-be emigrants in the Old World, the latter an audience in Sweden. Moreover, declarations of the above nature were balanced by the strongly nationalist pronouncements of Ole Bull, the Norwegian world-famous violinist whose attempt to create a Norwegian colony in Pennsylvania in the 1850 s failed badly. On one occasion, Danish and Swedish Americans were barred from a banquet held in his honor; indeed, it was Bull who queried, "Scandinavia, gentlemen, - may I ask where that land lies? It is not found in my geography; does it lie perhaps in the moon $?^{48}$

Summing up, even though the conditions for fostering a pan-Scandinavian spirit were probably never as favorable as during the years 1840 to 1890, usually the practical pan-Scandinavianism of everyday life remained a function of low immigrant numbers in combination, arguably, with processes of ascription and adversity. In the quintessentially "American" field of politics, it is true, down to the 1890s the "Scandinavian" label remained important. Overall, however, the pan-Scandinavianism of the early years did not manifest itself in truly convincing celebrations of common origins nor in the building of a consistent Scandinavian-American ideology rooted in the pan-Scandinavianism of everyday life.

46. Quoted from Grøngaard Jeppesen 2000, 46 (translated from the Danish).

47. Fredrika Bremer, The Homes of the New World: Impressions of America (trans. Mary Howitt, N.Y., 1853), vol. 1, 626; vol. 2, 57.

48. Lowell 1993, 704; Bull quoted from Babcock 1914, 15-16. 


\section{The era 1890-1917}

As several commentators have noted, during the 1890 s the practical panScandinavianism of the early years was weakened by stronger "national" commitments among Norwegian Americans, Swedish Americans and Danish Americans. ${ }^{49}$ One major factor accounting for this development was, quite simply, growing numbers. As noted, larger concentrations of Scandinavian Americans allowed for greater differentiation in the continued development of ethnic institutions and also for greater selectivity in the choice of friends and spouses. Why bother about pan-Scandinavian commitments if one could now afford to be picky? To be sure, the coming of age of a new generation of Scandinavian Americans born in the United States complicated the picture, for might it not be that these people, almost invariably fluent English speakers, worried less about Old-World local, regional or national ties and more about common ScandinavianAmerican background? Moreover, some of the Scandinavian immigrants arriving in America after 1900 appeared less interested in joining the traditional Scandinavian-American institutions, particularly the churches, than their forbears. ${ }^{50}$ Nevertheless, overall, increasing numbers tended to strengthen "national" institutions and identifications at the expense of practical pan-Scandinavianism.

Equally important for the Scandinavian Americans, if not for the socalled "new" immigrants from southern and eastern Europe arriving in large numbers during these years, the nativist pressure from the American environment subsided. Due probably in large part to their light hue, their Protestantism and the past tendency of many of them to settle in the countryside or small town rather than the city, Scandinavian Americans were generally viewed by Midwestern Yankees as "good" immigrants. True, in far-away Boston misunderstandings might still arise, as when a local clergyman exclaimed, "Why, Mr. Bergesen, I thought you were Norwegian," upon having asserted that Scandinavians, Poles and Italians were "undesirable immigrants." As the Lutheran Pastor B.E. Bergesen noted with smug reassurance, "He thought that Norwegians, Swedes and Danes were our best immigrants, but that Scandinavians were a separate

49. Jenswold 1985, 162; Lovoll 1991, 62; Runblom 1993, 234; Lowell 1993, 707.

50. Dag Blanck, Becoming Swedish-American: The Construction of an Ethnic Identity in the Augustana Synod, 1860-1917 (Uppsala 1997), 46. 
nation something like the Poles." ${ }^{51}$ In Boston, also, the respectable Youth's Companion associated "Chinese and Japanese, Scandinavians, Russians, Italians, Galicians and Poles" with "filth and lack of sanitary habits," yet when scolded by a Norwegian-language paper was quick to write the Scandinavian reference off as a slip of mind by an editor who actually "entertains the highest admiration for the [Scandinavian] race...." ${ }^{52}$

Episodes of this nature served only to confirm the impression that the Scandinavian Americans were usually not viewed as "new" immigrants, and also hinted that the former sometimes willingly joined the chorus criticizing the latter. Overall, Scandinavian Americans were now regarded as welcome strangers, even if Yankees might still query whether Norway was the capital of Stockholm, and notwithstanding that in Eau Claire, Wisconsin, the Swedish Americans had yet to put up with being called "Norwegian," in St. Paul, Minnesota, the Norwegian Americans with being called "Swedes," whereas in Racine, Wisconsin, as well as in Omaha, Nebraska, "we are all called 'Danes.", 53

If rising numbers and a friendly environment thus generally sustained the development of "national" sentiments at the expense of the pan-Scandinavian, so, too, did events back in the Scandinavian countries. The regions of each country were becoming increasingly integrated into national markets; with provincial barriers being broken by the railroads; with a host of newspapers obsessed by national issues entering into every nook and cranny of each country; with the movement of people from the countryside to the cities proceeding inexorably. As a result, over the decades each new wave of immigrants included steadily larger segments of people for whom thinking in national terms was no longer foreign: Political developments in the Scandinavian countries also played a major part in limiting supranational tendencies, as a nationally aroused Norway in 1905 struck a blow at pan-Scandinavianism by dissolving her union with Sweden.

A brief overview of the spheres of public and private activity touched upon in the previous section reveals, overall, this continued weakening of

53. Harald Graff to Amerika, August 9, 1893; B.E. Bergesen to Amerika, August 29, 1902. 
pan-Scandinavian tendencies. In the religious sphere, the main new developments took place below the pan-Scandinavian level, the DanishAmerican Lutherans in 1896 splitting into two churches, the NorwegianAmerican, on the other hand, completing a drawn-out process of national consolidation with the creation of the Norwegian Lutheran Church in 1917, and the Swedish-American developing a sense of Swedish-American identity within the Augustana Synod..$^{54}$ Quite symptomatically, by 1900 religious bodies with $f e w$ Scandinavian members, such as the Disciples of Christ, the Unitarians, the Moravians, the Salvationists, the Adventists and the Congregationalists boasted "Scandinavian" subdivisions, whereas the Baptist and Methodist churches, attracting more Scandinavian Americans, by 1900 had established both "Swedish" and "Norwegian-Danish" branches. ${ }^{55}$

Within the ethnic press, by 1890 the process of crystallization along nationality lines had largely been completed. After that point, some panScandinavian-American counterpressure was felt, however, Thus, in 1889 The North of Minneapolis began publication as an expressly Scandinavian-American yet English-language weekly, appealing particularly to second-generation Scandinavian Americans. ${ }^{56}$ Might not the English language, after all, serve as a unifier of this group? As one NorwegianAmerican observer pointed out more generally in 1914, "Scandinavian cooperation succeeds far better when it is provided with a more American foundation and the members are Americanized to such an extent that the English language is the language of the association." ${ }^{57}$ Such arguments, however, did not save The North from folding in the depression year of 1893; one Norwegian-American paper actually insinuated that The North by employing the English language was working in the service of American nativism. ${ }^{58}$ In Madison, Wisconsin, The Scandinavian American, a

54. Cf. John Jensen, The United Evangelical Lutheran Church: An Interpretation (Minneapolis 1964), 125-128; Lovoll 1984, 114; Blanck 1997.

55. O.N. Nelson, "Statistics Regarding the Scandinavians in the United States," in O.N. Nelson (ed.), History of the Scandinavians and the Successful Scandinavians in the United States, vol. 1 (Minneapolis, 2. ed., 1900), 263.

56. Cf. Luth Jaeger to Rasmus B. Anderson, October 14, 1891, the Papers of Rasmus B. Anderson, State Historical Society of Wisconsin.

57. Hansen 1914, 267 (translated from the Norwegian).

58. Wist 1914, 164; Posten, Superior, Wis., April 20, 1893. 
rather similar English-language venture, appeared in the early 1900s, arguing in its first issue that despite the conquests of the English language, "as long as "blood is thicker than water," a Scandinavian-American newspaper was justifiable. It survived for less than a decade. ${ }^{59}$

Thus, the attempts to forge a common Scandinavian-American identity on the basis of the English language via the press foundered. Scandinavian-language papers were less ambitious. In Wisconsin, the NorwegianAmerican Superior Tidende introduced a Swedish-Finnish column in 1899, but when the Swedish-American Nordvestern Härold began publication in the same city one year later, the experiment was dropped immediately. ${ }^{60}$

In their settlement patterns, there are no signs that Scandinavian Americans drew closer together between 1890 and 1917. True, the Wisconsin state census of 1905 revealed that in 133 of the state's 1,654 minor civil divisions at least 50 percent of the family heads were of Scandinavian parentage. More than 80 percent of the Scandinavian-American family heads in these 133 localities, however, lived in areas where one nationality group outnumbered the two others combined by a factor of at least two to one. ${ }^{61}$ In such neighborhoods, members of one of the other two Scandinavian-American nationality groups sometimes had to tread warily: "I like the company of my brother people, the Norwegians," reported one Swedish American from Beloit, Wisconsin, in 1894, "even though one should not attempt to do what Prime Minister Åkerhjelm proposed in Parliament in 1892, "to speak Swedish with the Norwegians." If I attempted to do that, maybe I'd be obliged to leave, just like he had to resign. No, it is better to 'speak a bit Norwegian;' they much prefer it that way." 62

Thus, in the rural Middle West, pan-Scandinavian settlements constituted the exception rather than the rule. True, in recently settled areas with few people, the pattern might yet be broken. "Recently a large com-

59. The Scandinavian American, November 10, 1902; the paper was last mentioned in the Wisconsin Blue Book of $1909,597$.

60. Superior Tidende, Wis., September 7, 1899, and July 5 and 26, 1900.

61. Calculations based on "A Retabulation of Population Schedules from the Wisconsin State Census of 1905," State Historical Society of Wisconsin.

62. "En Sörländing" to Svenska Amerikanaren, Chicago, September 4, 1894 (translated from the Swedish). 
pany of Norwegians, Danes and Swedes left Deadwood, North Dakota, to settle on the Sioux reservation where they intend to found a Scandinavian colony," reported Skandinaven. "These men have worked in the mines in the Black Hill region, but their Nordic sense of independence has driven them to become their own masters."63 Almost symptomatically, when in 1895 Johan Jørgensen, a Danish American, advertised in a newspaper for new settlers to come to West Denmark in Polk county, Wisconsin, he first asked for Danes to arrive; two years later he modified his appeal by calling for Danes or Norwegians; one year later he invited a "Scandinavian" veterinarian. ${ }^{64}$

In the cities, after 1890 earlier pan-Scandinavian cooperation increasingly gave way to "national" independence. Thus, in New York, Chicago and Minneapolis, some, if not all, of the earlier pan-Scandinavian settlements were succeeded by "national" enclaves. ${ }^{65}$ Similar tendencies could be observed in the organizational life of Scandinavian Americans. Thus, in 1892 what had been the Scandinavian Singers Union split into the American Union of Swedish Singers and the United Scandinavian Singers, a Danish-Norwegian group. ${ }^{66}$ Despite agitation among Scandinavian and Scandinavian-American laborers for pan-Scandinavian solidarity, union locals likewise experienced "national" fissures. ${ }^{67}$ Thus, in 1893 the Swedish-American members of the Chicago-based Scandinavian Typographical Union left what they held to be a Norwegian-Danish dominated organization and formed their own local; similar tendencies were apparent among Scandinavian-American painters in Chicago. ${ }^{68}$ Moreover, whereas the Norwegian-language Socialist paper Gaa Paa in 1904 presented itself as an "Organ for Scandinavian Workers in America," by 1910 it called itself a "Norwegian-Danish weekly."69 The

63. Skandinaven, March 9, 1890 (translated from the Norwegian).

64. Johan Jørgensen to Skandinaven, February 6, 1895; March 17, 1897; and July 6, 1898.

65. Jenswold 1985, 162; Christianson 1992, 112; Runblom 1993, 234.

66. Jenswold 1985, 162.

67. Jens Bjerre Danielsen, "Ethnic Identity, Nationalism and Scandinavianism in the Scandinavian Immigrant Socialist Press in the U.S," in Christiana Harzig and Dirk Hoerder (eds.), The Press of Labor Migrants in Europe and North America, 1880s to 1930s (Bremen 1985), 188.

68. Odd S. Lovoll, A Century of Urban Life: The Norwegians in Chicago before 1930 (Northfield, Minnesota, 1988), 171; Per Nordahl, Weaving the Ethnic Fabric: Social Networks Among Swedish-American Radicals in Chicago, 1890-1940 (Umeå 1994), 157-167.

69. Cf. for instance Gaa Paa, May 21, 1904; June 4, 1910. 
movement away from pan-Scandinavianism was further signaled during these years by the rise of regional rather than strictly national societies, the Norwegian-American bygdelag budding across the Middle West in the early 1900s and the Swedish-American hembygdsföreningar in the wake of World War One. ${ }^{70}$

In Scandinavian-American patterns of intermarriage, very few changes took place after 1890, as compared with the previous era. By 1900 , when Scandinavian immigrants did marry outside their own group they predominantly married other Scandinavians, and did so in the following order: Danish men and Norwegian women, Swedish men and Norwegian women and Norwegian men and Danish women. ${ }^{71}$

In the field of American politics, on the other hand, major transformations occurred. With the rise of Midwestern Progressivism after the turn of the century, a conscious attempt was made to root out the ethnic factor from state politics. If Progressive anti-corruption drives in the large cities tended to hurt political machines run by ethnic patron-politicians and their client networks, in state politics, with the spread of the direct-primary movement, the ethnically and regionally balanced state ticket became a thing of the past. True, a general association of the Scandinavian-American population element, particularly the Swedish- and Norwegian-American, with insurgent Republican politics and with the Progressive movement arose, yet unlike prior political arrangements, this found no semi-institutional expression: the Scandinavian-American politicians were no longer relegated to a symbolic place in politics as representatives primarily of an ethnic group. ${ }^{72}$

That circumstance notwithstanding, the ethnic institutions, particularly the press, continued to support politicians on national or "Scandinavian" grounds. The Scandinavian label, however, became increasingly awkward to apply, especially after Norway abrogated her union with Sweden in 1905. Thus, in Minnesota Norwegian-born U.S. senator Knute

70. Odd Lovoll, A Folk Epic: The Bygdelag in America (Boston 1975); Per Nordahl, "Lost and Found - A Place to Be: The organization of provincial societies in Chicago from the 1890s to 1933," in Daniel Lindmark (ed.), Swedishness Reconsidered: Three centuries of Swedish-American identities (Umeå 1999), 65-90.

71. Harald Runblom, "Chicago Compared: Swedes and Other Ethnic Groups in American Cities," in Anderson and Blanck 1992, 80-82.

72. Brøndal 1998, 402, 440-442; Charles E. Merriam and Louise Overracker, Primary Elections (Chicago 1928), 60-107. 
Nelson of Minnesota was placed in a particularly embarrassing position, because his constituency included both Swedish and Norwegian Americans. Speaking at a banquet in Minneapolis just nine days prior to Norwegian secession, he expressed the hope that the union between Norway and Sweden would not be broken, and that Denmark would in fact join it! In the ensuing days he was met by a barrage of criticism for catering to his Swedish-American supporters. ${ }^{73}$ In 1906, moreover, Wisconsin experienced the strange sight of the Norwegian-born James O. Davidson vying with the Swedish-American Irvine L. Lenroot for the Republican nomination for the governorship. In a campaign marked by Davidson's quiet appeals to his large Norwegian-American constituency he won in a landslide. ${ }^{74}$

Predictably, during these years pan-Scandinavian celebrations evaporated. Indeed, in 1905, Wisconsin's Norwegian-born governor was warned against participating in a a syttende mai celebration in Superior, for by so doing, "you are apt to make more enemies than friends among the Swedes." 75 More surprising, despite the strengthening of "national" tendencies after 1890, attempts to discuss a pan-Scandinavian-American identity actually multiplied. Whereas some observers pondered the fate of the pan-Scandinavian movement back in the Old World, most concentrated on the situation in the New. ${ }^{76}$ "I feel that w[h]ether we are Norwegians Swedes or Danish in this country and for that matter also at home, we should be first and foremost Scandinavians," noted one observer. ${ }^{77} \mathrm{~A}$. Ueland, son of the Norwegian parliamentarian Ole Gabriel Ueland, expressed his faith in a Scandinavian-American identity based on "our own merits" and uttered his contempt for the limited nationalism of his countrymen who were planning to erect a statue of Ole Bull in Minneapolis: "It is not any particular regard for Ole Bull that accounts for the enterprise. It is simply that we Norwegians must have a statue. The Danes have erected one for Andersen, the Swedes one for Linné, so we

73. Cf. Gieske and Keillor 1995, 266; Den Danske Pioneer, Omaha, Neb. June 22, 1905; Amerika, June $16,1905$.

74. Brøndal 1998, 366-404.

75. A.J. Pederson to James O. Davidson, March 20, 1905, the Papers of James O. Davidson, State Historical Society of Wisconsin.

76. Minneapolis Tidende, November 9, 1905; Superior Tidende, April 27, 1899.

77. L.M. Melander to James O. Davidson, July 28, 1899, the Papers of James O. Davidson. 
Norwegians must show that we can erect one too...." 78 Among the more bizarre pan-Scandinavian suggestions aired during these years was that of creating a new state, "New Scandia," out of the northern parts of Minnesota, Wisconsin and Michigan's northern peninsular. ${ }^{79}$

More important than these utterings and ideas, however, was the publication of two books and a number of articles by Scandinavian-American as well as Yankee writers, discussing Scandinavian-American history and identity. ${ }^{80}$ The two most important contributions were the books, i.e., the two-volume History of the Scandinavians and Successful Scandinavians in the United States (1893-97), edited by the Norwegian-American O.N. Nelson, and The Scandinavian Element in the United States, written by Kendrick Charles Babcock, a historian of non-Scandinavian background (1914).

In the former work, Nelson reviewed enthusiastically the history of Scandinavians and enumerated their main characteristics. Dwelling particularly on late ancient history, when Goths from Scandinavia descended on the Roman empire, and likewise reviewing the Viking age, Nelson identified Scandinavians collectively as courageous, freedom-loving individualists who not only exhibited a special predilection for migration, but who in fact also were the energetic representatives of a brave new world, adding fresh vigor to the classical, decaying civilizations of Southern Europe. What perfect Americans! Warming to his subject, Nelson summed up, "And whether we wander with the Goths when they plunder and destroy Rome, or sail with the Danes and Norwegians when they dethrone English kings and humble proud French monarchs, or live in the camps of the Swedes when Gustavus Adolphus and Charles the Twelfth dictate terms to popes and emperors, or accompany the Northern immigrants when they clear the dense forests of Wisconsin and subdue

78. A. Ueland to Rasmus B. Anderson, December 4, 1887; August 5, 1891, the Papers of Rasmus B. Anderson.

79. Superior Tidende, July $28,1911$.

80. Nelson 1900; Babcock, 1914; also Babcock, "The Scandinavian Contingent," Atlantic Monthly 77 (May, 1896), and "The Scandinavian Element in [the] American Population," American Historical Review, 16: 2 (1911); Hjalmar Hjorth Boyesen, "The Scandinavian in the United States," North American Review, 155 (November, 1892); Herbert N. Casson, "The Scandinavians in America," Munsey's Magazine 35: 5 (August, 1906). 
the wild prairies of Dakota, we find that they all excelled in endurance, heroism, and courage." 81

In a somewhat meaner spirit, capturing perfectly the ethnically chauvinistic temper of the World War One era, Kendrick Babcock asserted that the most desirable immigrants were those arriving from the regions "where the purest Baltic stock now exists, that is, north of a line running east and west through Brussels, and especially in north-central Germany and the Scandinavian peninsula." They contributed to American progress, unlike others who "lower its standards and retard its advancement." 82

The attempts by Nelson and Babcock to write pan-Scandinavian histories were never quite convincing. In a nationalistic rather than pan-Scandinavian vein Nelson thus insisted that the Norwegians as "bold sailors" and "daring adventurers" resembled the vikings more than did the Danes and Swedes. ${ }^{83}$ Babcock, on the other hand, simply wrote individual chapters on each nationality group, ascribing to each of them certain traits, an exercise that also the commentator Herbert N. Casson excelled in. ${ }^{84}$

Why this burst of interest in Scandinavian-American identity, which received institutional grounding with the establishment in 1910 of the American-Scandinavian Foundation and one year later of the Society for the Advancement of Scandinavian Studies? Why this enhanced interest in things Scandinavian and Scandinavian-American despite the weakening of the pan-Scandinavianism of everyday life? Two factors were of importance. First, as a spin-off effect of the generally heightened interest in nationality, room was made, simply, also for a discussion of pan-Scandinavian origins, despite the fact that most of the philiopietistic works of the era were written in a strictly national vein. Second, and more important, the books and articles about the Scandinavian Americans, as well as the other scholarly enterprises, were invariably English-language. Thus, it is fair to assume that the idea behind these initiatives was to involve an English-speaking audience and discuss Scandinavian-American history and identity on "American" terms, in the process ignoring the sad fate of

81. O.N. Nelson, "Characteristics of the Scandinavians and Review of Their History," in Nelson 1900, vol. $1,20$.

82. Babcock 1914, 11.

83. Nelson 1900, 24.

84. Babcock 1914, 17-18; Casson 1906, 614-616. 
practical pan-Scandinavianism in the settlements, the towns and the cities.

\section{The era after 1917}

The half century or so following World War One marked a definite turning point in Scandinavian-American history. As was the case for many other European groups, Scandinavian mass immigration to the U.S. came to an end during the 1920s. The cessation of immigration meant that the Scandinavian-American communities were gradually becoming dominated by American-born individuals. By 1940, for example, two thirds of the Swedish-American group was American-born, and the tendency was similar among the other groups. ${ }^{85}$

In many ways, the national differences among the Scandinavian Americans still prevailed, and Scandinavian-American organizations, as well as the sharply declining Scandinavian-language press, continued to be largely Danish-, Norwegian- or Swedish-American in character. ${ }^{86}$ Moreover, as the sociologist Peter A. Munch noted in the early 1950s, several traditionally Norwegian-American localities in the Middle West retained a "national" character, even if for instance the syttende mai celebrations at that point in time had "ceased completely" in the areas he investigated, and the mutual-aid fraternities, at least for now, had lost their social and ethnic functions. ${ }^{87}$ In the cities, on the other hand, the suburbanization process of the 1920s, and particularly in the aftermath of World War Two, caused the national enclaves to disintegrate; some suburban middle-class Scandinavian Americans continued to nurture a sense of ethnic identity, however, by assembling in vacation colonies on the outskirts of metropolitan areas. ${ }^{88}$

85. Sture Lindmark, Swedish America, 1914-1932: Studies in Ethnicity with Emphasis on Mlinois and Minnesota (Uppsala 1971), 28.

86. The Scandinavian-language press which in 1920 counted 73 weeklies (down from 94 in 1910) had by 1960 been reduced to 14, cf. Lindmark 1971, 222.

87. Peter A. Munch, "Segregation and Assimilation of Norwegian Settlements in Wisconsin," NorwegianAmerican Studies and Records 18 (1954), 137-138.

88. David Mauk, "Scandinavians," in Elliott Robert Barkan (ed.), A Nation of Peoples: A Sourcebook on America's Multicultural Heritage (Westport, Conn., 1999), 471. 
The above-named "national" tendencies notwithstanding, as the differences between the "homeland Scandinavians" and the Scandinavian Americans, to paraphrase H. Arnold Barton's terms, grew stronger, the ethnic identities developing among the three groups were also increasingly shaped by their gradual removal from the mother countries and their interaction with American society. ${ }^{89}$ The experience of World War One and its aftermath, with its strong emphasis on loyalty to the United States, also meant that the "American" element in the ScandinavianAmerican identities became increasingly emphasized. Symptomatically, in 1921 the Independent Scandinavian Workingmen's Association, a Wisconsin-based mutual-aid fraternity, changed its name to the Scandinavian-American Fraternity. ${ }^{90}$

It is, however, also possible to observe pan-Scandinavian developments in some areas. When it comes to marriage patterns, there is, as noted, a long-standing tendency of intermarriage between ScandinavianAmerican groups. Sture Lindmark has observed that between 1900 and 1930 Danes and Norwegians seemed more prone to marry outside their own group than the Swedes. ${ }^{91}$ More generally, the tendency to intermarry across Scandinavian lines has helped lay the foundations for the kind of sense of a pan-Scandinavian awareness that is so common among Danish, Norwegian and Swedish Americans today.

Larger ethno-religious trends in the U.S. also affected the Scandinavian Americans. In the 1940s and 1950s, sociologist Ruby Jo Reeves Kennedy introduced the concept of a triple melting pot in her studies of intermarriage patterns among ethnic groups in New Haven, Connecticut. American ethnic groups were indeed intermarrying, argued Kennedy, but mostly along religious lines. A " 'triple-melting-pot' assimilation is occurring through intermarriage, with Catholicism, Protestantism and Judaism serving as the three fundamental bulwarks." 92 Sociologist Will Herberg expanded upon this theme in his influential study of American religion,

92. Ruby Jo Reeves Kennedy, "Single or Triple Melting-Pot? Intermarriage in New Haven, 1870-1950," American Joumal of Sociology, 58 (July 1952), 56. 
Catholic, Protestant, Jew, from 1955. ${ }^{93}$ These trends suggest that the ethnic bonds among the Scandinavian-American groups were changing in nature, with a gradual expansion of identification taking place. As a result of that, a sense of pan-Scandinavian identity was no doubt emphasized within the larger Protestant cultural group, co-existing with the earlier national ethnic sentiments. Incidentally, as of 1990, as David Mauk points out, "all three Scandinavian American groups were among those most likely to marry outside the group." 94

The decades after 1965 have witnessed an increased interest in ethnicity in the United States. Thus, a renewed vitality of the organizational life among Danish, Norwegian and Swedish Americans attests to continued ethnic activities along national lines. Among the Swedes, for example, over 375 organizations, groups or institutions with a SwedishAmerican focus in the United States were noted in 1997. Many of these have been founded in the last several decades, suggesting the enduring significance of organized Swedish-American life. The Sons of Norway is an example of a continued active Scandinavian-American fraternal organization today. In 1995, its centennial year, it reported 360 U.S. lodges with some 67,000 members, to be compared with 153 lodges and 11,000 members just before World War One. ${ }^{95}$

As far as religion is concerned, the national Scandinavian lines have likewise become increasingly blurred in more recent times. American Lutheranism in the twentieth century was characterized by a series of mergers, through which ethnically based Lutheran denominations successively formed a number of larger entities. One phase of this movement ended in 1962 when Swedish and some Norwegian and Danish Lutherans came together in the Lutheran Church of America (LCA). In 1988 another merger created the Evangelical Lutheran Church in America (ELCA), which brought in the remaining Norwegian and Danish Americans who had belonged to the American Lutheran Church (ALC) from

93. Will Herberg, Protestant, Catholic, Jew: An Essay in American Religious Sociology (Garden City, N.Y., 1955). See also Philip Gleason, "Hansen, Herberg, and American Religion," in Peter Kivisto and Dag Blanck (eds.), American Immigrants and Their Generations: Studies and Commentaries on the Hansen Thesis After Fifty Years (Champaign, Ill., 1990).

94. Mauk 1999, 477.

95. Roger Baumann et al., American-Swedish Handbook (Minneapolis 1997); Lovoll 1998, 198. 
1960. ${ }^{96}$ These mergers have resulted in an intermixing of religious, cultural and ethnic traditions within the new church bodies, and the older ethnic boundaries and loyalties are clearly disappearing in many cases, and new configurations emerging, such as the affirmation of a Scandinavian tradition within, for example, the larger and ethnically quite diverse ELCA.

The question of whether ethnicity plays a political role among contemporary Scandinavian Americans is difficult to answer. The Americanization campaign of the World War One era and into the 1920s had generally silenced ethnic voices in politics, and ethnic questions remained subdued until the rise of the Civil Rights movement. Nevertheless, in the Middle West, most notably in Minnesota, the Scandinavian Americans, due simply to their large numbers, continued to play an important political role. Indeed, just as several Scandinavian Americans had earlier identified with Progressivism, during the 1920s and 1930s many Minnesota Scandinavian Americans affiliated with the Farmer-Labor party. Within that party, argues Bruce Larson, "the broader base of Scandinavian ethnic identity was a recognizable pattern...," with many Swedish Americans for instance voting for Norwegian-American leaders. Almost symptomatically, Floyd B. Olson, the Farmer-Labor leader, was of mixed Norwegian-Swedish ancestry. ${ }^{97}$

Today, impressionistic evidence from the traditional Scandinavian areas in the Midwest, especially in Minnesota, suggests that at least the hypothesis of a Scandinavian ethnic vote can still be advanced, especially on state and local levels. In an analysis of gubernatorial politics in Minnesota in the 1970s, Bruce Larson has thus suggested that Governor Wendell Anderson's Swedish background clearly was a factor which helped him win elections and a positive image in 1970 and $1976 .{ }^{98}$ Larson also

96. E. Clifford Nelson, Lutheranism in North America, 1914-1970 (Minneapolis 1972); Jette Mackintosh, Danskere i Midtvesten: Elk Horn-Kimballton bosattelsen 1870-1925 (Copenhagen 1993), 124. Cf. also Mark Granquist, "Conrad Bergendoff and the LCA Merger of 1962," Swedish-American Historical Quarterly, 46 (July 1995).

97. Bruce L. Larson, "Swedish Americans and Farmer-Labor Politics in Minnesota," in Hasselmo 1978, 215-217.

98. Bruce L. Larson, "Gubernatorial Politics and Swedish Americans in Minnesota: The 1970s and Beyond," in Philip J. Anderson and Dag Blanck, Swedes in the Twin Cities: immigrant life and Minnesota's urban frontier (Uppsala 2001), 333-339. 
points to the factor that "name recognition" can play an important role in Minnesota politics - that is, a Scandinavian-sounding name might be a political advantage. ${ }^{99}$

With these signs of the increasing significance of a practical pan-Scandinavianism in some spheres, at least, have recent years also witnessed conscious attempts to successfully strengthen senses of pan-Scandinavian-American identity? To some extent, this has definitely been the case. Thus, although most ethnic festivals among Scandinavian Americans continue to be celebrated along national lines, there are now also examples of some Scandinavian-American events. In September 1991, Scandinavian Americans in Turlock, California, thus introduced a Scandinavian-American festival which attracted several thousand visitors. The festival includes ethno-cultural and commercial dimensions as visitors can buy Scandinavian products and foods, listen to music and participate in various performances, look at art and even attend religious events. The official opening of the first festival, conducted by the mayor of Turlock dressed in a Viking helmet, included the unveiling of a locally built six foot high Dala horse. ${ }^{100}$

Food and foodways is one further area where it seems possible to observe a sense of pan-Scandinavian affinity. Although contents of the smörgåsbord can vary greatly between the Scandinavian groups, one dish in particular seems to have achieved a pan-Scandinavian status, namely the lutfisk or in its more common Norwegian form, lutefisk. It occupies a special position in the Scandinavian-American mind today. In the words of folklorist Barbro Klein, it has become "surrounded" by a great deal of "commotion" as people travel great distances to certain food stores to procure the item for at least the Norwegian- and Swedish-American Christmas table, especially in the Midwest. Moreover, there are a number of "lutefisk dinners" by Lutheran churches of Scandinavian origin which attract large numbers of people in November and December each year, and the lutefisk is also the "center of countless jokes" among Scandina- 
vian Americans, alluring to its "shaky consistency...tastelessness and the odor that it exudes when overcooked."101

Is it possible, perhaps, even to speak of an ideological dimension (in the widest sense of the term) to pan-Scandinavian-American identity since the "ethnic revival" of the 1960s and 1970s? The evidence is mixed, pointing to an ongoing process rather than an end result. The revival was initially associated with European-origin Americans with roots in eastern and southern Europe and with African Americans. In the 1980s and 1990s issues of ethnic diversity and pluralism have largely been focused on the discussions of multiculturalism, a debate which although it seems to have subsided some, is still ongoing. ${ }^{102}$ Although the ethnic revival and multiculturalism have not primarily focused on Scandinavian Americans - indeed some would probably question including these groups under a multicultural umbrella - these groups have also been affected by the past decades' renewed emphasis on ethnicity and cultural diversity in American life, as witnessed by the holding in 1973 of the Scanpresence conference in Minneapolis where representatives of a wide array of Norwegian-, Swedish-, Danish- and also Icelandic- and Finnish-American groups and organizations came together to discuss the future of the Scandinavian-American population element, "not only as an immigrant group in the context of a larger, all-engulfing society, but also as a group consisting of five very similar, but only slightly interacting national subgroups."103

More generally, affirming one's ethnic or racial background has become an integrated and accepted part of American life, and in the 2000 census, for example, over 90 percent of the ancestry identifications given indicated a national or ethnic origin from outside the U.S. and only some seven percent chose to identify their ancestry as "United States" or

101. Barbro Klein, "More Swedish Than in Sweden, More Iranian Than in Iran" in Bo Sundin (ed.), Upholders of Culture: Past and Present (Stockholm 2001), 71. See also Anne R. Kaplan, Marjorie A. Hoover and Willard B. Moore (eds.), The Minnesota Ethnic Food Book (St. Paul, Minn., 1986), 103; John Louis Anderson, Scandinavian Humor and Others Myths (Minneapolis 1986), 80-83.

102. See for instance Werner Sollors, "The Multiculturalism Debate as a Cultural Text," in Wendy F. Katin et al. (eds.), Beyond Pluralism: The Conception of Groups and Group Identities in America (Champaign, Ill., 1998).

103. Erik J. Friis, "Preface," in Friis (ed.), The Scandinavian Presence in North America (N.Y. 1976), xvi. 
"American."104 When asked, most Americans are thus able to specify one or several ethnic origins. Few systematic studies exist of contemporary ethnic patterns among Scandinavian Americans, but much of the evidence suggests that the tendency to continue to identify along national ethnic lines rather than pan-Scandinavian is continuing. ${ }^{105}$ In the 2000 Census the great majority among the Scandinavian Americans identified themselves with a particular Scandinavian nationality - 1.5 million persons of Danish ancestry, 4.5 million of Norwegian background, and 4.4 million claiming Swedish ancestry, while only 500,000 individuals stated that they were "Scandinavians." 106

At the same time the decline in language use that was already evident by the 1960s, when sociolinguist Joshua Fishman argued that the Scandinavian languages together with German, Czech and Finnish were characterized by "sharp losses," has continued. ${ }^{107}$ In 1990 the Census Bureau thus suggested that about 100,000 persons in the U.S. spoke Norwegian and Swedish and almost 50,000 Danish. ${ }^{108}$ Earlier assumptions that the sense of ethnicity would decrease as the language was lost have thus not been confirmed. Clearly, language is no longer a prerequisite for a sense of ethnic identification, and the vast majority of the Scandinavian Americans today speak English rather than Danish, Norwegian or Swedish. It may still be, however, that the growth of a Scandinavian-American identity alongside the purely "national" is being facilitated by this decline. As John Christianson has observed, the shift to English "allowed a new, broader Scandinavian-American identity to emerge," concluding that "until the shift to English occurred, a unified Scandinavian-American ethnicity had been unthinkable. Now it seemed inevitable."109

104. Data for 2000 is available on-line at http://factfinder.census.gov/.

105. Odd Lovoll, The Promise Fulfilled: A Portrait of Norwegian Americans Today (Minneapolis 1998); Tallgren 2000; Klein 2001.

106. http://factfinder.census.gov/, QT-02. Profile of Selected Social Characteristics; http://factfinder. census.gov/. PCT024. Ancestry First Reported; PCT025. Ancestry Second Reported. See also Mauk 1999, 477.

107. Joshua Fishman, Language Loyalty in the United States (The Hague 1966), 44-46.

108. Data from the 1990 census, available electronically at http://www.census.gov/population/socdemo/ ancestry/.

109. Christianson 1992, 119. 


\section{Conclusion}

What has it meant to be Scandinavian-American in the United States? Clearly, the significance and meaning of the term has varied over time. Still, it seems possible to isolate three periods of development. During the first phase, Scandinavian-American labels were invoked at a very early date and the term antedated the process of ethnicization among the Scandinavian Americans. During a second phase, when ethnicization truly came about, Scandinavian-American identity was superseded by national identities, and arguably also by regional identities, such as the bygdelag among Norwegian Americans and hembygdsföreningar among Swedish Americans. During the third phase, when Scandinavian Americans have moved into the mainstream of American society, the national identities have remained strong, but it also seems possible to observe a co-existence between them and pan-Scandinavian identities.

Moreover, a sense of Scandinavian-American identification seems to have been particularly prevalent in certain social arenas. Politics was the foremost of these arenas, where it has been possible to observe panScandinavian co-operation and to some extent voting behavior ever since the mid-nineteenth century. The political arena, of course, was an integral part of American society, and it can thus be argued that strong forces from the receiving society played an important role in shaping a Scandinavian-American identity in what we have called an ascriptive manner. Tendencies towards pan-Scandinavian identities can, however, also be observed in a private arena, relating more to the experiences of the different immigrant groups, as the discussion of intermarriage patterns has shown. Here, internal factors such as geographical proximity, religious developments and a sense of ethnic commonality have no doubt been important in explaining Scandinavian-American intermarriage trends.

Students of contemporary patterns of ethnic identification have suggested that the lines of ethnic demarcation in America have changed during the past decades. Today, sociologist Richard Alba argues, descendants of the European mass immigration of the nineteenth and early twentieth centuries are crossing both national and religious lines, and it is possible to see the emergence of a category of "European Americans," in addition to African Americans, Asian Americans and Hispanic Ameri- 
cans. ${ }^{110}$ In his study of contemporary Norwegian-American identity, Odd Lovoll has found little evidence of such a development and instead underlines the continued significance of a Norwegian-American identity. ${ }^{111}$ Still, the movement towards pan-Scandinavian ways of identification and co-operation that does exist in certain social spheres can be seen in the light of the development towards more inclusive ethnic groupings in contemporary American society. In that way, national ethnicities can exist side by side, or even as a part of broader ethnic categories. Thus, to be Danish-, Norwegian- or Swedish-American today does not need to preclude a sense of being Scandinavian-American. On the contrary, it seems possible to be both.

110. Richard Alba, Ethnic Identity: The Transfomation of White America (New Haven, Conn., 1990), $310-319$.

111. Lovoll $1998,182$. 